\title{
ANALISIS KEMISKINAN DITINJAU DARI TEMPAT TINGGAL, PEKERJAAN, PENDAPATAN, DAN PENDIDIKAN DI SULAWESI SELATAN
}

\author{
Hasmin*) \\ Dosen STIE Nobel Indonesia, Jl. Sultan Alauddin No. 212 Makassar \\ email: hasmintamsah@gamail.com \\ Mariah*) \\ Dosen STIE Nobel Indonesia, Jl. Sultan Alauddin No. 212 Makassar \\ email:mariah.nobel@yahoo.com
}

\begin{abstract}
Poverty is a complex social problem, therefore handling must be complex. This paper aims to uncover the real conditions of the poor in South Sulawesi using resourch gounded. Research shows that poor people in South Sulawesi forced to live in slum housing or live in a cramped room, inadequate sanitation, and no proper health standards. They work in the informal sector as a handyman bentor, pedicab drivers, masons, fishermen, or agricultural laborers. This has resulted in their income is very low, the average median Rp5.218 per day per person or Rp36.526 per day per family, while the expenditure of the poor at Rp6.147 per day per person or at Rp43.031 per day per family. Low income causes a very low level of their education. The long -term problem if it is down to the next generation will be very dangerous for the survival of their families in particular and the next generation in general.
\end{abstract}

Keywords : Poor, Shelter, Employment, Income, Education

\begin{abstract}
Abstrak : Kemiskinan adalah masalah sosial yang kompleks, oleh karena itu penanganannya harus kompleks. Tulisan ini bertujuan mengungkap kondisi riil warga miskin di Sulawesi Selatan dengan menggunakan metode gounded resourch. Penelitian menunjukkan bahwa warga miskin di Sulawesi Selatan terpaksa tinggal pada rumah kumuh atau tinggal dalam kamar yang sempit, sanitasi yang tidak memadai, dan tidak sesuai standar kesehatan yang layak. Mereka bekerja pada sektor informal sebagai tukang bentor, tukang becak, tukang batu, nelayan, atau buruh tani. Hal inilah yang berakibat pada pendapatan mereka sangat rendah yaitu rata-rata rata-rata Rp5.218 per hari per orang atau Rp36.526 per hari per Keluarga, sedangkan pengeluaran warga miskin sebesar Rp6.147 per hari per orang atau sebesar Rp43.031 per hari per keluarga. Pendapatan yang rendah menyebabkan tingkat pendidikan mereka sangat rendah. Problem jangka panjangnya adalah jika hal ini menurun ke generasi berikutnya akan sangat berbahaya bagi kelangsungan keluarga mereka secara khusus dan generasi penerus bangsa secara umum.
\end{abstract}

Kata Kunci : Miskin, Tempat Tinggal, Pekerjaan, Pendapatan, Pendidikan

\section{PENDAHULUAN}

Masalah kemiskinan adalah merupakan masalah yang krusial, tidak terkecuali di Sulawesi Selatan sehingga dalam penanggulangannya merupakan hal penting dan sifatnya mendesak.Oleh karena kemiskinan adalah merupakan persoalan multidimensi sehingga penyelesaiannyapun tidak boleh secara parsial tetapi harus konprehensip, sebagaimana dalam Mellenium Development Goals-
MDG (UN-ESCAP, 2006), secara tegas dinyatakan bahwa terdapat delapan dimensi yang bersifat komplementer dan inklusif dalam pencapaian sasaran pengentasan kemiskinan. Delapan dimensi MDG tersebut adalah: a) pengentasan kemiskinan dan kelaparan; b) perolehan pendidikan dasar secara universal; c) kesetaraan gender dan pemberdayaan perempuan; d) penurunan angka kematian bayi (di bawah lima tahun); e) perbaikan 
kesehatan ibu melahirkan; f) pemeberantasan HIV/AIDS, malaria, dan jenis penyakit menular lainnya; g) adanya kepastian kelestarian lingkungan, dan; $h$ ) pengembangan kerja sama global dalam pembangunan.

Sebagaimana telah dijelaskan sebelumnya bahwa kemiskinan itu bukan hanya disebabkan oleh faktor ekonomi saja, akan tetapi dari berbagai faktor. Myrdal (1968) dalam Poli, (2009) mengilustrasikan bahwa kondisi kemiskinan itu merupakan keterpaduan 5 (lima) kondisi yang berhubungan, antara 5 (lima) kondisi tersebut menghasilkan vicious circle of poverty, yang dapat dipecahkan dengan big push; "a plunge into cold water is better than a slow submersion". Keterpaduan lima kondisi yang dimaksud adalah: 1) output and incomes; 2) conditions of production; 3) levels of living; 4) attitudes towards life and work; and 5) social institutions. Dua dari lima penyebab yang sangat ditekankan Myrdal adalah: attitudes towards life and work dan social institutions.

Pada tahun pertama dari tiga tahun yang direncanakan penelitian ini ingin mengetahui kemiskinan yang ada pada lokasi penelitian secara mendalam dan komprehensip sehingga memilih melihat kemiskinan itu dari sisi mikro dan metode yang digunakan adalah grounded theory.

\section{KAJIAN LITERATUR}

Penelitian ini banyak terinspirasi dari tulisan Myrdal (1968) dalam Poli (2009) tentang lima kondisi kemiskinan yang diteliti di Asia termasuk Indonesia. Selanjutnya berbagai teori tentang kemiskinan misalnya Jordan, (2004) melihat kemiskinan antara faktor budaya dan struktur; Lamont \& Mario, (2006) melihat bagimana budaya mempengaruhi kemiskinan. Selanjutnya yang meletakkan penyebab pada faktor struktural seperti Rank, Yoon, dan Herschl, (2003).

Terakhir Bradshaw, (2005) yang membagi lima teori kemiskinan berdasarkan literatur kontemporer, yaitu; 1) kemiskinan yang disebabkan oleh kekurangan individu; 2) kemiskinan disebabkan oleh sistem budaya; 3) kemiskinan disebabkan oleh distorsi ekonomi, politik, dan sosial atau diskriminasi; 4) kemiskinan disebabkan oleh disparitas geografis; dan 5) kemiskinan disebabkan oleh saling ketergantungan.

Penelitian tentang kemiskinan banyak dilakukan, baik peneliti dalam negeri maupun luar negeri dengan pendekatan kuantitatif atau kualitatif saja, misalnya yang dilakukan oleh Davis, P., (2008) di Bangladesh, Simbowale Osinubi, T., (2003) di Nigeria, merupakan penelitian dengan pendekatan kuantitatif. Sedangkan yang menggunakan metode kualitatif di antaranya Otoluwa, (2009) di Manado dan Hasmin (2011) di Makassar.

\section{METODE PENELITIAN}

Penelitian ini menggunakan pendekatan kualitatif, yang akan mengungkap makna di balik semua tindakan yang dilakukan oleh subyek penelitian. Metode ini sangat cocok untuk menyelidiki suatu fenomena sosial dan masalah manusia. Hasilnya, peneliti akan membuat suatu gambaran kompleks tentang obyek penelitian. Pada tahun pertama ini, output akhirnya adalah publikasi pada jurnal nasional terakreditasi.

Penelitian ini mengacu pada Chariri (2009), Sugiyono (2008), Bogdan dan Taylor dalam Moleong, (2010:4), Creswell, (2008:438), Charmaz dalam Creswell (2008:439), yang menjelaskan tentang penelitian grounded theory. Kemudian diperkuat oleh Bungin (2007:115), Chariri (2009) tentang wawancara dan observasi serta proses 
penelitian grounded theory oleh Saroso, (2012:142-146).

\section{HASIL DAN PEMBAHASAN}

Hasil dari seluruh rangkaian metode yang digunakan dalam penelitian ini yang menghasilkan beberapa tema yang diangkat dari beberapa kategori yang ditemukan berulang pada semua lokasi penelitian. Kategori-kategori tersebut kemudian menjadi bahan klarifikasi dengan wawancara secara mendalam kepada informan yang hasilnya dapat disusun sebagai berikut:

\section{Tempat Tinggal}

Tempat tinggal sangat penting bagi kehidupan manusia pada umumnya tak terkecuali bagi warga miskin di Sulawesi Selatan. Tempat tinggal dalam penelitian ini adalah tempat yang digunakan bagi warga miskin sebagai tempat bagi anggota keluarga mereka seperti layaknya rumah atau kamar sewa yang dijadikan tempat tinggal bagi masyarakat secara umum. Namun kenyataannya adalah bahwa masyarakat miskin terutama masyarakat miskin perkotaan yang ada di Sulawesi Selatan sebagian besar tinggal di rumah kumuh, sewa, dan semipermanen.

Hasil penelitian menunjukkan bahwa warga miskin Sulawesi Selatan pada umumnya tinggal pada rumah kumuh, baik yang kepemilikannya sebagai hak milik pribadi (dibuat sendiri) ataupun yang disewa/kontrakan. Warga miskin umumnya tinggal pada rumah pribadi semipermanen dan tanah tempat berdirinya rumah adalah berstatus hak milik, yaitu $30.00 \%$ informan. Sedangkan sebagian yang lain tinggal pada rumah sewa dan kumuh yang kepemilikan tanah tempat berdirinya rumah tersebut adalah hak milik yaitu sebesar $16.67 \%$. Selebihnya ada yang tinggal pada rumah pribadi dan kumuh yang berdiri di atas tanah pemerintah, kemudian numpang pada rumah keluarga, tinggal pada rumah sewa baik semi permanen maupun rumah sewa kumuh khususnya yang tinggal dalam kota kabupaten.

Sejalan dengan hal tersebut World Bank (2003:40) dalam The World Bank, East Asia Urban Working Paper dikemukan bahwa:

"pada umumnya masyarakat miskin penghuni permukiman kumuh di perkotaan adalah masyarakat marjinal, yaitu masyarakat yang haknya terhadap tanah, rumah, infrastruktur dan pelayanan dasar, kesempatan kerja dan mendapatkan pinjaman, pemberdayaan dan partisipasi, rasa aman dan keadilan sangatlah terbatas atau terpinggirkan".

Mereka tinggal pada tempat tersebut karena tidak ada jalan lain mengingat sulitnya mendapatkan rumah atau tanah kosong, sebagaimana yang diungkapkan oleh informan berikut:

"saya terpaksa tinggal di sini karena tidak ada lagi kamar kosong yang lebih murah".

Lebih lanjut dikatakan bahwa: "apa boleh buat hanya beginilah nasib saya"

Yang lain mengatakan:

"bagaimanapun usaha yang saya lakukan kalau Tuhan tidak mengijinkan, maka saya tidak akan bisa kaya"

Selanjutnya mengatakan:

"kalau ada rejeki disyukuri berapapun adanya, rejeki datangnya dari Allah jadi berusaha saja, walaupun dalam hati kadang ada perasaan kenapa saya seperti ini terus"

Dari pernyataan-pernyataan inilah yang mengindikasikan bahwa mereka punya keyakinan akan adanya Tuhan yang mengatur semua apa yang ada di dunia ini. Mereka pasrah menerima keadaan mereka, selain dari faktor religi sehingga mereka pasrah yaitu ada faktor lain yang nampak dalam penelitian ini yaitu adanya keterbatasan yang dimiliki oleh mereka sehingga 
merasa bahwa mereka sudah sampai pada batas kemampuan yang dimiliki.

Mereka pasrah menerima keadaan mereka yang membuat motivasi mereka mencari pekerjaan yang lebih baik jadi rendah yang berakibat pada pendapatan rendah. Karena pendapatan rendah mengakibatkan mereka tidak dapat membuat atau menyewa rumah/kamar yang lebih baik.

\section{Pekerjaan}

Pekerjaan dalam penelitian ini adalah semua kegiatan yang dilakukan oleh Kepala Keluarga dan atau anggota keluarga yang lain yang dapat memperoleh balas jasa berupa upah atau gaji dari pengguna kegiatan atau hasil dari kegiatan tersebut. Berbicara tentang pekerjaan bagi masyarakat secara umum, maka mereka pastilah menginginkan pekerjaan yang mampu memberikan balas jasa yang pantas serta memiliki nilai prestise yang cukup tinggi dalam kehidupan mereka. Namun kebanyakan dari mereka tidak mampu mendapatkan pekerjaan yang prestise karena keadaan mereka tidak seberuntung dengan keadaan sebagian kecil masyarakat Indonesia umumnya.

Tabel 1

Karakteristik Informan Berdasarkan Pekerjaan Kepala Keluarga

\begin{tabular}{|c|c|c|c|c|}
\hline No. & Informan & Pekerjaan Kepala Keluarga & Frek. & Persentase \\
\hline 1 & Nomor 7 & Buruh harian & 1 & $3,33 \%$ \\
\hline 2 & Nomor 18 & Buruh Tambang & 1 & $3,33 \%$ \\
\hline 3 & Nomor $2,22,25,27, \& 28$ & Buruh Tani & 5 & $16,67 \%$ \\
\hline 4 & Nomor 19, 20, \& 21 & Buruh Tani \& Nelayan & 3 & $10,00 \%$ \\
\hline 5 & Nomor $6,8,24,26, \& 30$ & Jual Campuran & 5 & $16,67 \%$ \\
\hline 6 & Nomor $3 \& 4$ & Nelayan & 2 & $6,67 \%$ \\
\hline 7 & Nomor 23 & Penjahit & 1 & $3,33 \%$ \\
\hline 8 & Nomor $10,16, \& 17$ & Tani \& Tukang Becak & 3 & $10,00 \%$ \\
\hline 9 & Nomor $1 \& 5$ & Tukang Batu & 2 & $6,67 \%$ \\
\hline 10 & Nomor $9,11, \& 12$ & Tukang Becak \& Batu & 3 & $10,00 \%$ \\
\hline 11 & Nomor $13,14, \& 15$ & Tukang bentor & 3 & $10,00 \%$ \\
\hline \multirow[t]{2}{*}{12} & Nomor 29 & Tukang kayu \& Batu & 1 & $3,33 \%$ \\
\hline & Jumlah & & 30 & $100 \%$ \\
\hline
\end{tabular}

Sumber: Hasil olahan data primer, 2014

Mereka loyal terhadap pekerjaan mereka karena sadar akan kemampuan yang mereka miliki hanya cukup dengan pekerjaan yang mereka lakukan saat ini. Di samping itu karena desakan kebutuhan yang serba mendesak sehingga tidak ada pilihan lain selain mempertahankan pekerjaan mereka, walaupun mereka sadar bahwa pekerjaannya itu hanya sekedar mampu menutupi sebagian dari kebutuhan keluarga mereka, belum mampu sepenuhnya memenuhi kebutuhan hidup keluarganya secara utuh.Selain dari dua implikasi yang disebutkan sebelumnya, juga dapat menjelaskan bahwa dalam kegiatan sehari-hari kelompok warga miskin ini, keberadaan rentenir (pemodal) adalah hal yang nyata dan riil serta eksis.

Keterbatasan keahlian yang terlihat pada hasil penelitian ini disebabkan oleh beberapa faktor, di antaranya adanya ketakutan atau 
hambatan yang dilihat di luar diri mereka (the anemy is out there) untuk memulai sesuatu yang baru, di luar kebiasaan mereka selama ini atau yang keluarga mereka lakukan. Hal ini terjadi karena pada umumnya mereka tinggal dan berdiam dalam suatu daerah secara berkelompok dan cenderung memisahkan diri dari lingkungan di luar mereka terutama yang tinggal di kota. Ditemukan pula bahwa selain dari kesamaan nasib sebagai warga miskin, mereka hidup berkelompok karena ada persamaan lain, misalnya adanya hubungan keluarga, adanya hubungan suku, atau adanya sebuah persamaan identitas lain. Hal ini dibuktikan dengan ditemukannya warga miskin secara berkelompok pada daerah-daerah tertentu dalam masyarakat, sebagaimana dalam penelitian ini, ditemukannya kelompok bugis di Jeneponto, dan kelompok orang Makassar di Toraja.

Kecenderungan bersatu dalam kelompok-kelompok berdasarkan pada penjelasan sebelumnya, yang menyebabkan mereka dikategorikan sebagai perilaku memisahkan diri atau bertindak ekslusif ini dapat kita temukan selain dari temuan tadi, yaitu melalui pernyataan-pernyataan dari informan yang mengatakan bahwa:

"kalau yang tinggal di sini pak, semuanya dari Jeneponto, Takalar, dan Gowa saja, kalau dari daerah lain tinggalnya di tempat lain".

Selain dari adanya keinginan memisahkan diri dari yang disebabkan karena faktor internal, ada juga ditemukan pemisahan yang cenderung sebagai akibat faktor eksternal.Hal ini ditunjukkan dengan pernyataan warga yang tinggal di sekitar warga miskin yang mengatakan bahwa:

"kadang saya takut tinggal di sekitar sini karena pada umumnya yang tinggal di sini itu yang kurang mampu, kita tahu kan mereka sering minum dan mabukmabukan".

Kenyataan ini mengimplikasikan bahwa sadar atau tidak, ada batasan di antara mereka menyebabkan hubungan mereka menjadi kaku dan cenderung menjadi hubungan formalistik, misalnya menjadi hubungan antara sopir dan majikan, tukang batu dengan yang punya rumah, tukang becak dengan muatan, penjaga toko dengan bos, dan seterusnya. Hubungan ini selalu menempatkan seseorang menjadi di atas (atasan) orang lain dan sebaliknya. Pada akhirnya berimplikasi pada kesempatan memperoleh pekerjaan yang jadi terbatas karena informasi yang hanya terbatas pada internal komunitas saja.

\section{Pendapatan}

Pendapatan dalam penelitian ini adalah jumlah balas jasa atau pemberian yang diterima oleh kepala keluarga dan atau anggota keluarga yang turut serta dalam proses produksi barang dan atau jasa yang menjadi sumber pendapatan keluarga mereka. Rumah tangga, baik pada level masyarakat biasa maupun masyarakat elit pasti membutuhkan biaya untuk memenuhi kebutuhan hidupnya sehari-hari. 
Tabel 2

Karakteristik Informan Berdasarkan Pendapatan Keluarga

\begin{tabular}{|c|c|c|c|c|c|}
\hline \multirow{2}{*}{$\frac{\text { No }}{1}$} & \multirow{2}{*}{$\begin{array}{l}\text { Informan } \\
\text { Nomor } 02\end{array}$} & \multicolumn{2}{|c|}{ Kisaran Pendapatan } & \multicolumn{2}{|c|}{$\begin{array}{l}\text { Kisaran Pengeluaran } \\
\text { Keluarga (perbulan) }\end{array}$} \\
\hline & & $\mathrm{Rp}$ & $450.000,00$ & $\mathrm{Rp}$ & $615.000,00$ \\
\hline 2 & Nomor 22 & $\mathrm{Rp}$ & $450.000,00$ & $\mathrm{Rp}$ & $750.000,00$ \\
\hline 3 & Nomor 25 & $\mathrm{Rp}$ & $450.000,00$ & $\mathrm{Rp}$ & $922.191,78$ \\
\hline 4 & Nomor 27 & $\mathrm{Rp}$ & $500.000,00$ & $\mathrm{Rp}$ & $705.000,00$ \\
\hline 5 & Nomor 28 & $\mathrm{Rp}$ & $525.000,00$ & $\mathrm{Rp}$ & $720.610,00$ \\
\hline 6 & Nomor 12 & $\mathrm{Rp}$ & $620.000,00$ & $\mathrm{Rp}$ & $810.000,00$ \\
\hline 7 & Nomor 07 & $\mathrm{Rp}$ & $650.000,00$ & $\mathrm{Rp}$ & $750.460,00$ \\
\hline 8 & Nomor 11 & $\mathrm{Rp}$ & $715.000,00$ & $\mathrm{Rp}$ & $1.150 .000,00$ \\
\hline 9 & Nomor 23 & $\mathrm{Rp}$ & $750.000,00$ & $\mathrm{Rp}$ & $880.000,00$ \\
\hline 10 & Nomor 29 & $\mathrm{Rp}$ & $820.000,00$ & $\mathrm{Rp}$ & $990.883,56$ \\
\hline 11 & Nomor 09 & $\mathrm{Rp}$ & $825.000,00$ & $\mathrm{Rp}$ & $957.000,00$ \\
\hline 12 & Nomor 16 & $\mathrm{Rp}$ & $900.000,00$ & $\mathrm{Rp}$ & $975.000,00$ \\
\hline 13 & Nomor 26 & $\mathrm{Rp}$ & $925.000,00$ & $\mathrm{Rp}$ & $1.082 .000,00$ \\
\hline 14 & Nomor 21 & $\mathrm{Rp}$ & $950.000,00$ & $\mathrm{Rp}$ & $1.080 .000,00$ \\
\hline 15 & Nomor 24 & $\mathrm{Rp}$ & $976.000,00$ & $\mathrm{Rp}$ & $992.000,00$ \\
\hline 16 & Nomor 18 & $\mathrm{Rp}$ & $1.000 .000,00$ & $\mathrm{Rp}$ & $1.230 .000,00$ \\
\hline 17 & Nomor 15 & $\mathrm{Rp}$ & $1.240 .000,00$ & $\mathrm{Rp}$ & $1.405 .000,00$ \\
\hline 18 & Nomor 03 & $\mathrm{Rp}$ & $1.250 .000,00$ & $\mathrm{Rp}$ & $1.625 .000,00$ \\
\hline 19 & Nomor 13 & $\mathrm{Rp}$ & $1.250 .000,00$ & $\mathrm{Rp}$ & $1.685 .000,00$ \\
\hline 20 & Nomor 20 & $\mathrm{Rp}$ & $1.250 .000,00$ & $\mathrm{Rp}$ & $1.500 .000,00$ \\
\hline 21 & Nomor 30 & $\mathrm{Rp}$ & $1.300 .000,00$ & $\mathrm{Rp}$ & $1.225 .000,00$ \\
\hline 22 & Nomor 01 & $\mathrm{Rp}$ & $1.312 .500,00$ & $\mathrm{Rp}$ & $1.425 .000,00$ \\
\hline 23 & Nomor 05 & $\mathrm{Rp}$ & $1.320 .000,00$ & $\mathrm{Rp}$ & $1.650 .000,00$ \\
\hline 24 & Nomor 14 & $\mathrm{Rp}$ & $1.375 .000,00$ & $\mathrm{Rp}$ & $1.546 .100,00$ \\
\hline 25 & Nomor 17 & $\mathrm{Rp}$ & $1.400 .000,00$ & $\mathrm{Rp}$ & $1.727 .000,00$ \\
\hline 26 & Nomor 10 & $\mathrm{Rp}$ & $1.600 .000,00$ & $\mathrm{Rp}$ & $1.820 .000,00$ \\
\hline 27 & Nomor 19 & $\mathrm{Rp}$ & $1.625 .000,00$ & $\mathrm{Rp}$ & $1.950 .000,00$ \\
\hline 28 & Nomor 06 & $\mathrm{Rp}$ & $1.740 .000,00$ & $\mathrm{Rp}$ & $1.600 .000,00$ \\
\hline 29 & Nomor 08 & $\mathrm{Rp}$ & $1.800 .000,00$ & $\mathrm{Rp}$ & $2.100 .000,00$ \\
\hline 30 & Nomor 04 & $\mathrm{Rp}$ & $2.905 .000,00$ & $\mathrm{Rp}$ & $2.860 .000,00$ \\
\hline \multicolumn{2}{|c|}{ Rata-rata per Bulan per Keluarga } & $\mathbf{R p}$ & $1.095 .783,33$ & $\mathbf{R p}$ & $1.290 .941,51$ \\
\hline \multicolumn{2}{|c|}{ Rata-rata per Bulan per Orang } & $\mathbf{R p}$ & $156.540,48$ & $\mathbf{R p}$ & $184.420,22$ \\
\hline \multicolumn{2}{|c|}{ Rata-rata per Hari per Keluarga } & $\mathbf{R p}$ & $36.526,11$ & $\mathbf{R p}$ & $43.031,38$ \\
\hline \multicolumn{2}{|c|}{ Rata-rata per Hari per Orang } & $\mathbf{R p}$ & $5.218,02$ & $\mathbf{R p}$ & $6.147,34$ \\
\hline
\end{tabular}

Sumber: Hasil olahan data primer, 2014

Biaya tersebut dapat dialokasikan dari pendapatan Kepala Keluarga maupun seluruh anggota keluarga yang terlibat bekerja. Pendapatan dan pengeluaran dalam suatu rumah tangga dapat dipastikan akan berbeda tergantung dari status sosial dan pekerjaan yang dilakukan oleh seseorang.

Pendapatan keluarga warga miskin di Sulawesi Selatan sangat kecil, disamping karena jumlah anggota keluarga yang bekerja sedikit juga karena jenis pekerjaan mereka yang terbatas pada pekerjaan yang memang tidak berskill tinggi sehingga balas jasa yang diterima juga kecil. Keadaan ini diakibatkan karena tingkat pendidikan mereka umumnya sangat rendah (akan dijelaskan pada sub pokok bahasan pendidikan pada pembahasan selanjutnya). Di samping itu kemauan 
mencoba pekerjaan lain selain dari apa yang mereka kerjakan selama ini sangat kurang, mereka mengatakan:

"saya jadi tukang becak sejak dulu hanya pekerjaan ini yang bisa saya kerjakan, saya tidak bisa jadi tukang batu juga tidak bisa jadi tukang kayu karena sejak kecil tidak pernah belajar karena itu sekarang saya pulang ke kampung jadi burh tani saja".

Keterbatasan keterampilan dan sulit mencoba pekerjaan baru menjadi kendala mereka dalam memperluas lapangan pekerjaansehingga apapun pekerjaan yang mereka lakoni sejak awal,akan menjadi profesi bagi mereka seumur hidup. Peranan isteri dalam mengisi waktu luang guna membantu suami dalam mencari nafkah juga masih minim bagi keluarga warga miskin di Sulawesi Selatan ini.

Pendapatan yang minim menyebabkan mereka mengubah pola konsumsi mereka, baik pola konsumsi makanan maupun non-makanan. Padahal kita ketahui bahwa makanan merupakan kebutuhan utama bagi tubuh manusia, namun demikian karena keterbatasan pendapatan maka sebagian besar dialokasikan untuk memenuhi kebutuhan makanan.Bahkan dalam kondisi yang sangat sulit, untuk memenuhi kebutuhan makananpun terpaksa harus lebih mengutamakan makan nasi saja dan mengurangi konsumsi lauk pauk yang biasanya justru mempunyai kandungan protein yang tinggi

\section{Pendidikan}

Pendidikan yang dimaksud dalam penelitian ini adalah jenjang pendidikan formal. Pada dasarnya, sebagian besar informan merasa bahwa pendidikan sangat penting bagi mereka, tetapi kenyataannya bahwa tingkat pendidikan mereka sangat rendah. Hal ini dapat dilihat dari tabel 3 berikut ini:

Tabel 3

Karakteristik Informan Berdasarkan Pendidikan Kepala Keluarga

\begin{tabular}{|c|c|c|c|c|}
\hline No & Informan & Pendidikan Kepala Kel. & Frek. & $\begin{array}{c}\text { Persen- } \\
\text { tase }\end{array}$ \\
\hline 1 & $\begin{array}{c}\text { Nomor } 02,03,04,05,06,07,09,10,11,13 \\
14,15,17,19, \& 22\end{array}$ & Tidak Tamat SD & 15 & $50,00 \%$ \\
\hline 2 & Nomor $08,12,18,20,21,25,27,28, \& 30$ & Tamat SD & 9 & $30,00 \%$ \\
\hline 3 & Nomor $01,23,24,26, \& 29$ & Tamat SMP & 5 & $16,67 \%$ \\
\hline \multirow[t]{2}{*}{4} & Nomor 16 & Tamat SMA & 1 & $3,33 \%$ \\
\hline & Jumlah Informan & & 30 & $100,00 \%$ \\
\hline
\end{tabular}

Sumber: Hasil olahan data primer, 2014

\begin{abstract}
Anak-anak warga miskin memiliki partisipasi dan kualitas terhadap akses lembaga pendidikan yang bermutu sangat terbatas, di samping itu kemungkinan putus sekolah juga sangat besar. Hal ini diungkapkan informan dalam penelitian ini:
\end{abstract}

"katanya bebas pembayaran uang sekolah tetapi masih banyak yang kita harus bayar, misalnya beli LKS, baju seragam, sumbangan lain-lain yang bagi kami tidak sanggup bayar sehingga anak saya hanya bisa sampai tamat SD saja".

Selain karena tidak mampu membayar uang sekolah, hasil pengamatan di lokasi penelitian menunjukkan bahwa anak-anak sekolah dari kalangan warga miskin di Sulawesi Selatan, sepulang dari sekolah sangat jarang mereka membuka pelajaran untuk 
mengulangi pelajaran dari sekolah karena dua faktor.Pertama, orang tua mereka yang relatif pendidikan rendah tidak mampu membantu anak-anak mereka mengulangi pelajaran di rumah.Kedua, anak-anak sekolah dari warga miskin ini lebih suka bermain dengan teman-temannya atau sebagian membantu orang tua mencari nafkah sehingga tidak ada waktu untuk belajar.Akibatnya adalah mereka kurang mampu menyerap pelajaran di sekolah sehingga ada dari mereka terpaksa tidak bisa naik kelas dan akhirnya berhenti atau yang bisa selesesai menganggap bahwa tamat SD sudah cukup, yang penting sudah bisa membaca dan menulis.

Dalam jangka panjang, bila mereka berkeluarga maka anak-anak dari keturunan warga miskin ini akan mengikuti perilaku orang tuanya, sehingga generasi selanjutnyapun tidak akan jauh berbeda dengan para orang tuanya, kerena kualitas pendidikan yang rendah, maka mereka tidak dapat bersaing dalam dunia kerja formal sehingga turun tumurun mereka bekerja pada sektor non-formal. Warga miskin di Sulawesi Selatan secara finasial memang tidak dapat menyekolahkan anak-anak mereka akan tetapi ini bukanlah alasan satu-satunya bagi mereka, hal ini dapat dilihat dari ungkapan warga terhadap pendidikan:

"saya mau sekolahkan anak sampai sarjana tetapi makan sehari-hari saja kami kadang harus pinjam sama tetangga, kalaupun sekarang ini ada program sekolah gratis dari pemerintah tetapi tetap masih banyak yang dibayar, selain itu tetangga saya sudah sekolah sampai sarjan tetapi tetap menganggur juga sampai saat ini”.

Pandangan warga miskin bahwa dengan bersekolah mereka akan mendapatkan pekerjaan yang lebih baik, kandas dengan kenyataan yang ada di dalam masyarakat bahwa masih banyak pengangguran yang sebenarnya adalah berpendidikan dan bahkan sampai pada tingkat sarjana. Filosofi bersekolah agar mencerdaskan kehidupan bangsa, setelah cerdas kapasitas diri mereka meningkat sehingga diharapkan memperoleh pekerjaan yang lebih baik, dinafikan oleh mereka karena kenyataan adanya pengangguran terdidik dalam masyarakat.

\section{KESIMPULAN}

Kemiskinan yang dialami oleh warga miskin di Sulawesi Selatan bila dilihat dari keadaan mereka saat ini dapat dideskripsikan dalam 4 (empat) kategori sebagai berikut:

Tempat tinggal; warga miskin Sulawesi Selatan pada umumnya tinggal pada rumah kumuh, baik yang kepemilikannya sebagai hak milik pribadi (dibuat sendiri) ataupun yang disewa/kontrakan. Hanya $30.00 \%$ informan tinggal pada rumah pribadi semipermanen yang berdiri di atas tanah hak milik. Sedangkan sebagian yang lain tinggal pada rumah sewa dan kumuh yang berdiri di atas tanahhak milik yaitu sebesar $16.67 \%$. Selebihnya ada yang tinggal pada rumah pribadi dan kumuh yang berdiri di atas tanah pemerintah, kemudian numpang pada rumah keluarga, tinggal pada rumah sewa baik semi permanen maupun rumah sewa kumuh khususnya yang tinggal dalam kota kabupaten.

Pekerjaan; warga miskin di Sulawesi Selatan umumnya bekerja pada sektor informal dan tidak tetap, di mana $16,67 \%$ bekerja sebagai buruh tani dan jual campuran sedangkan 10,00\% adalah sebagai buruh tani \&tukang becak, buruh tani \& nelayan, tukang becak \& batu, serta tukang bentor. Selain itu masih ada sebagai tukang jahit, buruh tambang, dan burh harian serta tukang kayu \& kayu masingmasing 3,33\% merupakan pekerjaan yang dilakukan oleh para informan. 
Akibatnya adalah mereka sulit meningkatakan pendapatan karena pekerjaan yang sangat bergantung pada kesehatan dan pisik mereka.

Pendapatan; penghasilan warga miskin di Sulawesi Selatan rata-rata Rp5.218 per hari per orang atau Rp36.526 per hari per Keluarga, sedangkan pengeluaran warga miskin sebesar Rp6.147 per hari per orang atau sebesar Rp43.031 per hari per keluarga. Hal ini jauh lebih kecil dari garis kemiskinan bila kita mengacu pada US\$1 per hari per orang (asumsi US\$1 setara dengan Rp12.000 saat ini). Jika kita membandingkan antara pendapatan dan jumlah pengeluaran keluarga warga miskin di Sulawesi Selatan selalu defesit setiap bulannya. Ini disebabkan karena di samping memang pendapatan tesebut sangat kecil, jumlah anggota keluarga warga miskin juga sangat besar, yaitu rata-rata 6 (enam) orang per keluarga.

Pendidikan; pada umumnya warga miskin di Sulawesi Selatan tidak tamat SD yaitu sebesar $50,00 \%$ atau 15 informan, sedangkan yang tamat SD hanya 9 orang atau $30,00 \%$, yang tamat SMP hanya 5 orang atau $16,67 \%$ saja, selebihnya yaitu hanya 1 orang yang tamat SMA atau 3,33\%. Kenyataan ini mengindikasikan bahwa warga miskin di Sulawesi Selatan memiliki tingkat pendidikan yang sangat rendah serta partisipasi mereka terhadap pendidikan sangat rendah. Problem jangka panjangnya adalah jika hal ini menurun ke generasi berikutnya akan sangat berbahaya bagi kelangsungan keluarga mereka secara khusus dan generasi penerus bangsa secara umum.

\section{DAFTAR PUSTAKA}

Bungin, B. 2007.Penelitian Kualitatif. Prenada Media Group: Jakarta.
Bradshaw, T. K, 2006.Theories of poverty and anti-poverty programs in community development. Rural Poverty Research Centre (RPRC) Working Paper, pp. 06-05 February, 2006. Diunduh Maret 2013.

Chariri, A., 2009. Landasan Filsafat dan Metode Penelitian Kualitatif, Paper disajikan pada Workshop Metodologi Penelitian Kuantitatif dan Kualitatif, Laboratorium Pengembangan Akuntansi (LPA), Fakultas Ekonomi Universitas Diponegoro Semarang, 31 Juli - 1 Agustus 2009, http__unesa.info_elearning download_a6a47959fd0c1d3f d65414831ce397df_diunduh pada tanggal 12 Juni 2010.

Creswell, John W. 2008. Educational Research: Planning, Conducting, and Evaluating Quantitative and Qulitative Research. New Jersey: Prentice Hall.

Hasmin, 2011.Analsis Kemiskinan di Kota Makassar. [Disertasi Universitas Hasanuddin, Makassar].

Hasmin, 2011.Kemiskinan dan Solusi Kemiskinan Perkotaan di Indonesia.Jurnal Akmen Vol.8 No. 4, Desember 2011

Jordan, G., 2004. The Causes of Poverty - Cultural vs. Structural Can There Be a Synthesis?www.asu.edu/mpa/ Jordan.pdf - diunduh Maret $\underline{2013}$. 
Lamont, M., and Mario Luis Small, 2006. How Culture Matters for Poverty: Thickening our Understanding. National Poverty CenterWorking Paper Series. Diunduh Maret 2013.

Millenium Depelopment Goals Report, 2006, Uzbekistanplanipolis.iiep.unesco.org/.../ Uzbekistan\%20MDG\%20Apr il\%202006.pdf

Osinubi, T., Simbowale, 2003.Urban Poverty in Nigeria: A Case Study of Agege Area of Lagos State, Nigeria. Departement of Economics Faculty of The Social Sciences University of Ibadan, Ibadan, Nigeria, Agustus 2003. tokunbosinubi@yahoo.co.uk.

Otoluwa, Nining, H., 2009. Kebijakan Pemerintah dan Reaksi
Keluarga Miskin terhadap Program Peanggulangan Kemiskinan: Studi Kasus di Kota Manado. Perpustakaan PPs Unhas.

Poli W.I.M., 2009. Perekonomian Indonesia dan Strategi Pembangunan-Bahan Ajar, Pascasarjana Universitas Hasanuddin Makassar.

Rank, Mark R.; Yoon, Hong-Sik; Hirschl, Thomas A. (2003).American Poverty as a Structural Failing: Evidence and Arguments, Journal of Sociaology and Social Welfare 30 (4): 3-29.

Saroso, Samiaji, 2012. Dasar-dasar Penelitian Kualitatif. Jakarta, PT. Indeks. 